\title{
Bivalve mollusks in Ulsan Bay (Korea)
}

\author{
Konstantin A. Lutaenko \\ A.V. Zhirmunsky Institute of Marine Biology, Far East Branch of the Russian Academy of Sciences, Vladivostok 690041, Russia
}

\begin{abstract}
The bivalve molluscan fauna of Ulsan Bay, East Sea coast of Korea, is summarized, based on original and literature data. The fauna consists of 61 species belonging to 20 families. Seven species are identified only to genus level. Two species (Carditellopsis toneana (Yokoyama, 1922), Carditidae and Fulvia hungerfordi (G.B. Sowerby III, 1901), Cardiidae) are new records for the East Sea coast of Korea, and one species (Crenella decussata (Montagu, 1808), Mytilidae) is a new record for Korea. Biogeographically, Ulsan Bay's bivalve fauna is subtropical with a predominance of tropical-subtropical species, 21 species, or $39 \%$ of the total species number, subtropical, 14 species, or $26 \%$, and subtropical-boreal (mostly subtropical-lowboreal), 11 species, $21 \%$, totalling $86 \%$. A remarkable feature of the Ulsan Bay fauna is the presence of tropical-subtropical species not found in Yeongil Bay but common in tidal flats and shallow waters of the Yellow Sea and the southern part of Korea. A cold water mass appearing off the southeast coast of Korea near Ulsan in summer seems responsible for the presence of boreal-arctic species in this area.
\end{abstract}

Key words: bivalve mollusks, Korea, Ulsan Bay, fauna, biogeography.

\section{INTRODUCTION}

Ulsan Bay (Ulsan-man) is one of the bays on the continental coast of the East Sea (Sea of Japan) located in southeastern South Korea (Gyeongsangnam-do, South Gyeongsang Province), about $72 \mathrm{~km}$ north-northeast of Busan, the second largest city in Korea. There are no papers dealing specifically with the molluscan fauna of this bay.

The Korean marine molluscan fauna has received much attention in the last twenty years with the publication of color atlases (Kwon O.-K. et al., 1993; 2001; Min D.-K. et al., 2004), general lists (Je, 1989; Lee J.-S. and Min D.-K., 2002), regional lists (Noseworthy et al., 2007), and an annotated and illustrated catalogue of bivalves of the continental

Received: January 13, 2014; Revised: March 22, 2014; Accepted: March 27, 2014

Corresponding author : Konstantin A. Lutaenko

e-mail: lutaenko@mail.ru

1225-3480/24515

This is an Open Access article distributed under the terms of the Creative Commons Attribution Non-Commercial License with permits unrestricted non-commercial use, distribution, and reproducibility in any medium, provided the original work is properly cited. coast of the East Sea (Lutaenko and Noseworthy, 2012). However, the fauna is still poorly known at regional and local levels, and the geographical distribution of many species is not clearly understood. We have undertaken a regional survey of bivalves in Ulsan Bay, located in an intermediate biogeographical area between the boreal (temperate) and subtropical (warm-temperate) zones of the East Sea.

\section{MATERIAL AND METHODS}

Material for this study was collected in August 1997 (Fig. 1; Table 1) during a benthic survey conducted by Dr. Lee Eui-Hyeong, formerly of Korea University, and Dr. E.I. Shornikov and Dr. K.A. Lutaenko of the A.V. Zhirmunsky Institute of Marine Biology, Far East Branch of the Russian Academy of Sciences.

The material collected consists of living and dead mollusks (empty shells) collected by dredging at a depth range of 12-56 m on soft substrata in Ulsan Bay at ten stations. The dredge was a small, simple apparatus, 36 cm-wide, designed by Dr. E.I. Schornikov, with a nylon sack with meshes of $0.15 \mathrm{~mm}$ x $0.15 \mathrm{~mm}$ and an inserted sieve with meshes of 1.5 $\mathrm{mm}$ x $1.5 \mathrm{~mm}$ (see for details Lee et al., 2000). One 


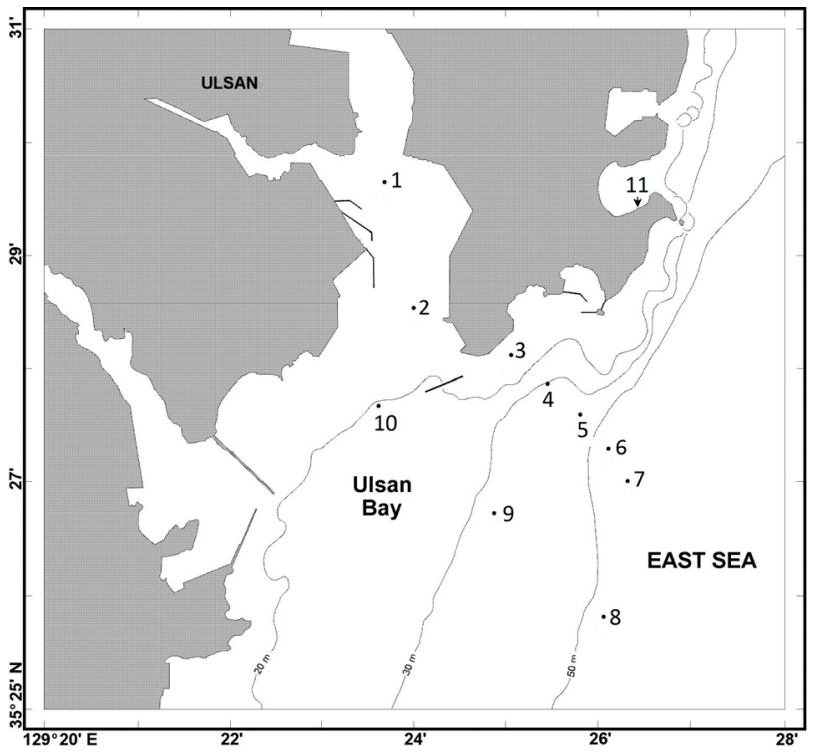

Fig. 1. A map of Ulsan Bay showing sampling stations.

sample was additionally taken at Ilsan Beach on hard substrate with sea grass and algae by snorkelling in a depth of 1-3 m. All dredge samples were sieved to exctract meobenthic organisms; the macrobenthic fraction was fixed in 50-70\% alcohol. Macrobenthos was sorted into empty shells and animals collected alive; fixed mollusks were dried after a fixation period of 1-2 years. Mollusks were collected at 11 sampling stations (Fig. 1;Table 1). In total, 1087 specimens of bivalves were examined. The collection studied is deposited in the Zoological Museum, Far Eastern
Federal University, Vladivostok (hereafter ZMFU). A list of the ostracod fauna from the same samples was published by Lee et al. (2000).

We have also used literature data on bivalve species records taken from ecological/environmental studies by Yi et al. (1982), Rho et al. (1997), Shin H.C. et al. (2001) and Yoon S.-P. et al. (2009). Zonalbiogeographical characteristics of molluscan species were taken from the catalogue of the bivalves of the continental coast of East Sea by Lutaenko and Noseworthy (2012); biogeographical analysis and terms based on zonal-geographical approach are described and discussed in detail in a number of works (Scarlato, 1981; Kussakin, 1990; Lutaenko, 1993).

\section{REGIONAL SETTING}

Ulsan Bay is a small bay located on the southeastern coast of the Korean Peninsula. The 47 km long Taehwa River passes through downtown Ulsan and flows into Ulsan Bay. The river, which cuts across Ulsan City from east to west, originates in the valley of Giji Mountain and Baekun Mountain. Two other rivers flow into the southern area of the bay, Gosa Stream, between Ulsan and Jangsaeng harbors, and Woihang River, flowing into Onsan Bay, part of Ulsan Bay.

Climatically, one of the most distinct features of the Korean Peninsula is the Asian monsoon system; in

Table 1. List of sampling stations in Ulsan Bay

\begin{tabular}{ccccc}
\hline Station No. & Geographical position & Depth, m & Bottom \\
\hline 1 & $35^{\circ} 29^{\prime} 39^{\prime \prime} \mathrm{N}, 129^{\circ} 23^{\prime} 41^{\prime \prime} \mathrm{E}$ & 12 & Grey mud \\
2 & $35^{\circ} 28^{\prime} 33^{\prime \prime} \mathrm{N}, 129^{\circ} 24^{\prime} 00^{\prime \prime} \mathrm{E}$ & 15 & Grey mud \\
3 & $35^{\circ} 28^{\prime} 08^{\prime \prime} \mathrm{N}, 129^{\circ} 25^{\prime} 03^{\prime \prime} \mathrm{E}$ & 15 & Coarse sand \\
4 & $35^{\circ} 27^{\prime} 53^{\prime \prime} \mathrm{N}, 129^{\circ} 25^{\prime} 27^{\prime \prime} \mathrm{E}$ & 31 & Grey mud \\
5 & $35^{\circ} 27^{\prime} 37^{\prime \prime} \mathrm{N}, 129^{\circ} 25^{\prime} 48^{\prime \prime} \mathrm{E}$ & 43 & Grey mud \\
6 & $35^{\circ} 27^{\prime} 19^{\prime \prime} \mathrm{N}, 129^{\circ} 26^{\prime} 06^{\prime \prime} \mathrm{E}$ & 55 & Grey mud \\
7 & $35^{\circ} 27^{\prime} 01^{\prime \prime} \mathrm{N}, 129^{\circ} 26^{\prime} 18^{\prime \prime} \mathrm{E}$ & 56 & Grey mud \\
8 & $35^{\circ} 25^{\prime} 49^{\prime \prime} \mathrm{N}, 129^{\circ} 26^{\prime} 04^{\prime \prime} \mathrm{E}$ & 53 & Grey mud \\
9 & $35^{\circ} 26^{\prime} 44^{\prime \prime} \mathrm{N}, 129^{\circ} 24^{\prime} 53^{\prime \prime} \mathrm{E}$ & 34 & Grey sandy mud \\
11 (Ilsan Beach) & $35^{\circ} 27^{\prime} 30^{\prime \prime} \mathrm{N}, 129^{\circ} 23^{\prime} 37^{\prime \prime} \mathrm{E}$ & 22 & Grey mud \\
\hline
\end{tabular}


winter cold, dry conditions prevail; in summer, a warm, moist climate exists owing to the influence of a local southeasterly flow spiraling from the quasi-stationary, semi-permanent North Pacific high pressure system to the southeast. Therefore, most of Korea experiences cold, dry winters, but hot and humid summers (Kwon and Lee, 2010). Annual mean air temperatures around Ulsan are between $13^{\circ} \mathrm{C}$ and $14^{\circ} \mathrm{C}$; in January around $1-2^{\circ} \mathrm{C}$, and in August $24^{\circ} \mathrm{C}$ (Kwon and Lee, 2010). Mean sea surface temperatures (SSTs) around Ulsan Bay are between $17^{\circ}$ and $18^{\circ} \mathrm{C}$ (http://www.worldclimateguide.co.uk). However, the mean SSTs in the vicinity of the coast are generally lower than those in off-shore regions (Kang and Jin, 1984b). Maximum sea temperatues in Ulsan can reach as high as $26^{\circ} \mathrm{C}$ in August, with a minimum of $13^{\circ} \mathrm{C}$ in February and March (http://www.worldclimateguide.co.uk). The annual mean salinity at the sea surface in the area off Ulsan is between 33.5 and $33.7 \%$, and $34.05 \%$ at a depth of $30 \mathrm{~m}$ (Kang and Jin, 1984a). The eastern coast of South Korea has small tidal differences, a third of one meter at the most (Kwon and Lee, 2010). It is well known that a cold water mass appears off the southeast coast of Korea near Ulsan in summer (Lee K.-B., 1978; Kim C.H. and Kim K., 1983; Lee J.C. and $\mathrm{Na}$ J.Y., 1985). The upwelling cold waters are saltier than the resident surface waters, and an extraordinarily high concentration of dissolved oxygen suggests that the upwelling waters are closely connected to the southward flowing North Korea Cold Current (Lee T. and Kim I.-N., 2003). The lowest surface water temperature appears near the coast, and this phenomenon is the most remarkable characteristic of the coastal cold water in Korea: in August, SSTs can drop to $17-20^{\circ} \mathrm{C}$ around Ulsan, while they reach 25-26.9 ${ }^{\circ} \mathrm{C}$ offshore (Lee K.-B., 1978). At $20 \mathrm{~m}$ deep, temperatures can be as low as $13-15^{\circ} \mathrm{C}$ near the coast between Ulsan and Pohang in August, while they increase to $24-25^{\circ} \mathrm{C}$ offshore (Lee J.C. et al., 2003).

The substrate of the coastal area south of Yeongil Bay is composed of clay or mud (Shin and Koh, 1993). At sampling stations in Ulsan Bay, grey mud predominated, but coarse sand was found at one station (Table 1).
The coastal waters of Ulsan Bay are polluted with heavy metals: the levels of $\mathrm{Cd}, \mathrm{Pb}, \mathrm{Hg}, \mathrm{Cu}, \mathrm{Zn}, \mathrm{Co}$, and $\mathrm{Mn}$ were very high in the tissues of the mussel Mytilus galloprovincialis Lamarck, 1819, and comparable with elevated concentrations of these elements in Mytilus sp. reported for other geographical areas (Szefer et al., 2004). In Ulsan Bay, the concentrations of $\mathrm{Cu}, \mathrm{Pb}$ and $\mathrm{Zn}$ in bottom sediments began to increase during the 1960s, but have remained almost unchanged since 1970 (Lee K.W. et al., 1988). Approximately, 280,000 t and 300,000 t of domestic and industrial waste, respectively, is discharged daily into the coastal region from Ulsan City and industrial complexes (Khim et al., 2001).

Ulsan City was historically a fishing port and agricultural marketing centre but, since the opening of rail and road communications to Seoul and Busan in 1962, it has developed as an industrial centre. Now, Ulsan is home to the world's largest auto production complex and fifth largest automaker, the biggest South Korean shipyard and shipbuilder, and the globe's second largest petrochemical complex; it is regarded as one of the Great Industrial Cities (Jakobs, 2011). Thus, it is especially important to study the regional biota due the to rapid change of the marine environment in the last decades.

\section{ANNOTATED LIST OF BIVALVE MOLLUSKS COLLECTED IN ULSAN BAY}

Family Nuculidae Gray, 1824

1. Acila sp.

Sampling station: 10 .

Material examined: 1 specimen.

Occurrence: A valve fragment was collected at a depth of $22 \mathrm{~m}$, in mud.

2. Nucula (Leionucula) tenuis (Montagu, 1808)

Plate 1, fig. B

Sampling stations: 1 , 4-9.

Material examined: 579 specimens.

Occurrence: Live specimens were collected at a depth of $12-56 \mathrm{~m}$, in mud and sandy mud; empty shells at 
43-56 m.

Comments: A close species is Nucula (Leionucula) ovatotruncata (Scarlato in Volova et Scarlato, 1980) depicted by Scarlato (1981) and Lutaenko and Noseworthy (2012), although it was synonymized with $N$. tenuis by Coan et al. (2000). N. ovatotruncata is differentiated from $N$. tenuis by the less dorso-ventrally broadened shell and the relatively shorter resilifer (Scarlato 1981). N. ovatotruncata is believed to be distributed in southern Primorye (between Possjet and Kievka Bays) in the northwestern East Sea and in the South Kurile Islands area (between Hokkaido and Kunashir Isls.) but it has never been recorded by Japanese malacologists. Other related species are Nucula mirifica Dall, 1907 and Nucula niponica Smith, 1885. Korean specimens from Ulsan and Yeongil bays (Lutaenko et al., 2003) resemble, in shell outline, the Chinese $N$. tenuis figured by Xu (1984, pl. 1, fig. 4) and a specimen designated as "Nucula paulula A. Adams" in Ito et al. (1986, pl. 34, fig. 8) from off the Noto Peninsula. According to $\mathrm{Xu}$ (1999), N. tenuis occupies the greater part of the Yellow Sea, and it is found also in the South Sea of Korea (Korea Strait) (Je et al., 1991). Kamenev (2013) recorded this species as deep as $1075 \mathrm{~m}$ in the East Sea.

\section{Nucula (Nucula) paulula A. Adams, 1856 \\ Plate 1, fig. A}

Sampling station: 3 .

Material examined: 1 specimen.

Occurrence: An empty shell was taken at a depth of 15 $\mathrm{m}$, in coarse sand.

Family Yoldiidae Dall, 1908

4. Yoldia (Cnesterium) notabilis Yokoyama, 1922

Plate 1, fig. C

Sampling stations: $1,5-10$.

Material examined: 27 specimens.

Occurrence: Live mollusks were collected at a depth of 12-55 m, and empty shells at 34-56 m, in mud and sandy mud.

\section{Portlandia sp.}

Sampling station: 10 .

Material examined: 2 specimens.

Occurrence: Empty shells were taken at a depth of 22 $\mathrm{m}$, in mud.

Family Arcidae Lamarck, 1809

6. Arca boucardi Jousseaume, 1894

Plate 1, fig. D

Sampling station: 5 .

Material examined: 1 specimen.

Occurrence: An empty shell was taken at a depth of 43 $\mathrm{m}$, in mud.

\section{Striarca symmetrica (Reeve, 1844) \\ Plate 1, fig. $\mathrm{F}$}

Sampling station: 10.

Material examined: 2 specimens.

Occurrence: Empty shells were collected at a depth of $22 \mathrm{~m}$, in mud.

Comments: We follow a new system of Carter et al. (2011) and assign this species to the tribe Striarcini MacNeil, 1937 in the subfamily Noetiinae R. Stewart, 1930 which was previously regarded as a separate family, Noetiidae.

Family Mytilidae Rafinesque, 1815

8. Mytilus (Mytilus) galloprovincialis Lamarck, 1819 Plate 1, fig. G

Sampling stations: $1,11$.

Material examined: 4 specimens.

Occurrence: Empty shells were collected at a depth of 1-12 m.

9. Musculista senhousia (Benson in Kantor, 1842)

Sampling station: 6 .

Material examined: 3 specimens.

Occurrence: Empty shells were taken at $55 \mathrm{~m}$, in mud. 
10. Septifer (Mytilisepta) virgatus (Wiegmann, 1837) Plate 1, fig. J

\section{Sampling station: 3 .}

Material examined: 2 specimens.

Occurrence: Empty shells were taken at a depth of 15 $\mathrm{m}$, in coarse sand.

Comments: We have in our possession only subadult specimens of $S$. virgatus. This species is bluish in color and adults have smoothish shells, although juvenile specimens, which have fewer and larger, rounded ribs, may be purplish.

\section{Modiolus (Modiolus) kurilensis Bernard, 1983}

\section{Plate 1, fig. $\mathrm{H}$}

\section{Sampling station: 11.}

Material examined: 1 specimen.

Occurrence: A live specimen was collected at a depth 1-3 m, among sea grass and algae.

\section{Crenella decussata (Montagu, 1808)}

Plate 1, fig. E

Sampling stations: 5,6 .

Material examined: 2 specimens.

Occurrence: Empty shells were collected at a depth of 43-55 m, in mud.

Comments: A new record for Korea. This species was previously known from the northern Pacific including the East Sea (Peter the Great Bay and western Sakhalin), being a widely distributed boreal-arctic species (Scarlato, 1960; 1981; Coan et al., 2000). Scarlato (1960) described a southern subspecies, Crenella decussata laticostata Scarlato, 1960 characterized by a higher shell with strong widely-spaced radial riblets, and distributed in the East Sea and the southern and northern Kurile Islands. As Huber (2010) mentioned, Adams (1862) described Crenella casta A. Adams, 1862, C. cornea A. Adams, 1862, C. crocea A. Adams, 1862, and C. sculptilis A. Adams, 1862 from the East Sea, but their types were never depicted and they could not be located in the Natural History Museum (London).
These species were listed as valid in the catalogue of Higo et al. (1999) in the genus Arvella Bartsch in Scarlato, 1960 but their relationship with other North Pacific Crenella Brown, 1827 and Solamen Iredale, 1924 are not known. Arvella includes two large species, A. japonica (Dall, 1897), shell length up to 37 $\mathrm{mm}$, distributed in the northern East Sea, southern Sea of Okhotsk, south Kurile Islands and Hokkaido, and A. manshurica Bartsch in Scarlato, 1960, shell length up to $43 \mathrm{~mm}$, an endemic species of the Sea of Okhotsk (eastern Sakhalin, Sakhalinsky Bay, Shantar Islands, western Kamchatka, and Hokkaido) (Scarlato, 1981). Arvella has clear radial ribs and is rather close to Musculus Röding, 1798 ("rhomboidal-ovate, solid, rougher radial sculpture and larger than Crenella, brownish and varnished periostracum" (Huber, 2010, p. 547)). A. manshurica was synonymized with $C$. decussata by Higo et al. (1999) which is not substantiated at all. On the other hand, Habe (1977), Kafanov (1991) and Higo et al. (1999) kept as distinct Crenella yokoyamai Nomura, 1932 (nom. nov. pro Crenella divaricata Yokoyama, 1922 non d'Orbigny, 1847) (Yokoyama, 1922; Nomura, 1932) which is regarded as a synonym of $C$. decussata, along with $C$. decussata laticostata (Coan et al., 2000; Coan and Valentich-Scott, 2012). Scarlato (1981) did mention the resemblance of $C$. decussata laticostata and $C$. yokoyamai. Illustrations of syntypes of $C$. divaricata (Yokoyama, 1922, pl. 15, figs. 10, 11; Oyama, 1992, pl. 27 , figs. 3, 4) show that this species (C. yokoyamai) is indeed a synonym of $C$. decussata (3 syntypes in the University Museum, University of Tokyo: http://www.um.u-tokyo.ac.jp/web_museum/database_en. $\mathrm{html}$ ). It is of interest that Yokoyama (1922) mentioned that $C$. decussata lives in the Korea Strait and he was aware of the species described by Adams (1862).

The Pliocene Crenella delicatula Yokoyama, 1926 (holotype in the University Museum, University of Tokyo: http://www.um.u-tokyo.ac.jp/web_museum/ database_en.html) and Crenella parvula Yokoyama, 1926 (3 syntypes in the University Museum, University of Tokyo: http://www.um.u-tokyo.ac.jp/web_museum/ database_en.html) (Yokoyama, 1926, p. 301. pl. 36, 
figs. 7 and 8, respectively; Sawane Formation, Sado Is.) has nothing in common with Recent C. decussata. Higo et al. (1999) mentioned C. delicatula as a "synonym" of C. yokoyamai; WoRMS (http://www.marinespecies.org/aphia.php-p=taxdetails\&i $\mathrm{d}=539117$ ) takes the former species as a synonym of $C$. decussata. An illustration of C. yokoyamai in Ito et al. (1986, pl. 40, fig. 1) from the eastern East Sea is identical with our material from Ulsan Bay. Much work needs to be done to revise this regional complex of Crenellinae.

\section{Lithophaga sp.}

\section{Sampling station: 5 .}

Material examined: 1 specimen.

Occurrence: A valve fragment was collected at a depth of $43 \mathrm{~m}$, in mud.

Family Ostreidae Rafinesque, 1815

14. Crassostrea gigas (Thunberg, 1793)

Plate 1, fig. I

\section{Sampling station: 5 .}

Material examined: 1 specimen.

Occurrence: An empty shell was taken at a depth of 43 $\mathrm{m}$, in mud.

\section{Family Pectinidae Wilkes, 1810}

15. Pectinidae sp. juv.

Sampling stations: $3,5,10$.

Material examined: 3 specimens.

Occurrence: Empty shells were taken at a depth of $15-43 \mathrm{~m}$.

Family Thyasiridae Dall, 1900

16. Axinopsida subquadrata (A. Adams, 1862)

Sampling stations: $1,4-10$.

Material examined: 46 specimens.

Occurrence: Live mollusks were collected at a depth of $12-55 \mathrm{~m}$, in mud and sandy mud; empty shells were found down to a depth of $56 \mathrm{~m}$.
Comments: Lutaenko and Noseworthy (2012) and Kamenev (2013) stated that further study of this species and comparison with the widely-distributed north-eastern Pacific Axinopsida sericata (Carpenter, 1864) are required. Moreover, a number of lucinid and/or thyasirid species described by A. Adams (1862) from the East Sea as Myrtea and Cryptodon were nearly forgotten and subsequently cited (as Myrtea, Thyasira and Axinopsida) only a few times in catalogues of the Japanese fauna (Kuroda and Habe, 1952; Higo et al., 1999). They are much in need of critical revision.

\section{Thyasira tokunagai Kuroda et Habe, 1951}

Plate 2, fig. A

Sampling stations: 5, 6, 8-10.

Material examined: 12 specimens.

Occurrence: Live mollusks were collected at a depth of 34-53 $\mathrm{m}$, in mud and sandy mud; empty shells were taken at $22-55 \mathrm{~m}$.

Family Carditidae Férussac, 1822

18. Carditellopsis toneana (Yokoyama, 1922)

Plate 2, fig. D

\section{Sampling station: 3 .}

Material examined: 4 specimens.

Occurrence: Empty shells were collected at a depth of $15 \mathrm{~m}$, in coarse sand.

Comments: A new record for the East Sea coast of Korea. In Korea, C. toneana was previously found in Jeju Island (Min D.-K. et al., 2004; Noseworthy et al., 2007). It is distributed from northwestern Honshu (Iwate Prefecture) and southwards in the East Sea, including Sado Island, to Kyushu, and along the Pacific side of Japan at a depth of 20-150 m, in fine sand (Higo et al., 1999).

Family Crassatellidae Férussac, 1822

19. Salaputium cf. unicum Hayami et Kase, 1993-

Plate 2, fig. C

Sampling station: 5 . 
Material examined: 1 specimen.

Occurrence: An empty shell was collected at a depth of $43 \mathrm{~m}$, in mud.

Comments: This small-sized crassatellid, rarely exceeding $3 \mathrm{~mm}$ in maximum length, was described from subtidal caves of Ie, Shimoji, and Irabu Islets, Ryukyu Islands (Hayami and Kase, 1993), and then Lutaenko et al. (2003) recorded this species from Yeongil Bay. However, it was observed that specimens from the latter locality have a slightly concave posterodorsal margin, while specimens from the Ryukyu Islands exhibit a slightly convex posterodorsal margin, and bear more sharp commarginal lamellae on the shell surface. Recently, Huber (2010) stated that another allied species, Crassatella sublamellata Kobelt, 1885 was originally described from Japan, and a small series of similar specimens has been available from subtidal caves at Palau; the smallest are, in shape, very close to S. unicum, whereas the largest approaches C. sublamellata. Huber (l.c.) believes that there is little doubt that $\mathrm{S}$. unicum is only a juvenile cave form of C. sublamellata, changing shape during its growth and becoming more elongate and subrectangular in adults. The status of the genus Salaputium Iredale, 1924 itself is not clear; there are about 13 species mostly from Australia.

Family Cardiidae Lamarck, 1809

20. Fulvia hungerfordi (G.B. Sowerby III, 1901)

Plate 2, fig. F

Sampling station: 10 .

Material examined: 3 specimens.

Occurrence: Empty shells were taken at a depth of 22 $\mathrm{m}$, in mud.

Comments: A new record for the East Sea coast of Korea. This species is recorded for Jeju Is. (Noseworthy et al., 2007).

Family Chamidae Lamarck, 1809

21. Chama sp. juv.

Sampling station: 3 .

Material examined: 2 specimens.
Occurrence: Empty juvenile shells were taken at a depth of $15 \mathrm{~m}$, in coarse sand.

Family Lasaeidae Gray, 1842

22. Nipponomysella oblongata (Yokoyama, 1922)

Plate 2, fig. B

Sampling station: 10 .

Material examined: 1 specimen.

Occurrence: An empty shell was found at a depth of 22 $\mathrm{m}$, in mud.

Family Kelliellidae P. Fischer, 1887

23. Alveinus ojianus (Yokoyama, 1927)

Plate 2, fig. E

Sampling stations: 3, 5, 9, 10.

Material examined: 81 specimens.

Occurrence: Empty shells were taken at a depth of $15-43 \mathrm{~m}$, in mud, sandy mud, and coarse sand.

Family Mactridae Lamarck, 1809

24. Raeta (Raetellops) pulchella (Adams et Reeve, 1850)

Plate 2, fig. $\mathrm{H}$

Sampling stations: 4-6, 9, 10.

Material examined: 34 specimens.

Occurrence: Empty shells were taken at a depth of $22-43 \mathrm{~m}$, and a living mollusk at $55 \mathrm{~m}$, in mud and sandy mud.

Comments: Neaera tenuis Hinds, 1844 may be an earlier name for this species (Huber, 2010). According to Higo et al. (1999), this species is distributed as far south as the South China Sea and Australia, and is known from the northern East Sea (Dulenina, 2013); this species may represent a complex of species. At least, specimens from Singapore (Wong, 2009, fig. 16a, b) are dissimilar in shell shape to typical East Sea specimens.

Family Tellinidae Blainville, 1814

25. Macoma (Macoma) incongrua (Martens, 1865)

Plate 2, fig. G 
Sampling station: 5 .

Material examined: 1 specimen.

Occurrence: An empty shell was taken at a depth of 43 $\mathrm{m}$, in mud.

26. Macoma (Macoma) tokyoensis Makiyama, 1927

Plate 2, fig. I

Sampling station: 5 .

Material examined: 2 specimens.

Occurrence: Empty shells were taken at a depth of 43 $\mathrm{m}$, in mud.

27. Angulus vestalioides (Yokoyama, 1920)

Plate 2, fig. $\mathrm{K}$

Sampling station: 10 .

Material examined: 4 specimens.

Occurrence: Empty shells were taken at $22 \mathrm{~m}$, in mud.

28. Moerella iridescens (Benson, 1842)

Plate 2, fig. J

Sampling stations: 5, 9, 10.

Material examined: 8 specimens.

Occurrence: Empty shells were taken at a depth of 22-43 $\mathrm{m}$, in mud and sandy mud.

Comments: This species was previously known only from Busan on the East Sea coast of Korea (Lutaenko and Noseworthy, 2012).

Family Semelidae Stoliczka, 1870

29. Theora (Endopleura) lubrica A.A. Gould, 1861 Plate 3, fig. C

Sampling stations: 1, 2, 4-6, 8, 10, 11.

Material examined: 104 specimens.

Occurrence: Empty shells were taken at a depth of 1-55 m, and live specimens from 22-53 m, in mud.

Family Solecurtidae d'Orbigny, 1846

30. Azorinus abbreviatus (Gould, 1861)

Plate 3, fig. A
Sampling station: 10 .

Material examined: 4 specimens.

Occurrence: Empty shells were taken at a depth of 22 $\mathrm{m}$, in mud.

\section{Family Ungulinidae Gray, 1854 \\ 31. Felaniella sowerbyi Kuroda et Habe, 1951}

Sampling station: 9.

Material examined: 2 specimens.

Occurrence: Empty shells were taken at a depth of 34 $\mathrm{m}$, on sandy mud.

\section{Cycladicama cumingii (Hanley, 1844)}

Plate 3, fig. B

Sampling stations: 5, 9, 10.

Material examined: 24 specimens.

Occurrence: Empty shells were taken at a depth of 22-43 m, in mud and sandy mud.

33. Cycladicama cf. lunaris (Yokoyama, 1927)

Plate 3, fig. D

Sampling stations: 5, 6, 9, 10.

Material examined: 11 specimens.

Occurrence: Empty shells were taken at a depth of 22-55 m, in mud and sandy mud.

Family Veneridae Rafinesque, 1815

34. Dosinia (Dosinella) penicillata (Reeve, 1850)

Plate 3, fig. F

Sampling stations: 5, 10.

Material examined: 2 specimens.

Occurrence: Empty shells were taken at a depth of 22-43 m, in mud.

Comments: Records of "Dosinella corrugata (Reeve, 1850)" from Korea (Min D.-K. et al., 2004) clearly represent true $D$. penicillata. This species was long known in the Russian literature as Dosinia angulosa (Philippi, 1847) (Kafanov and Lutaenko, 1997). Dosinia trailli A. Adams, 1855 might be a synonym of $D$. penicillata (see possible types: Fischer-Piette and 
Delmas, 1967, pl. 13, figs. 4-12).

35. Ruditapes philippinarum (A. Adams et Reeve, 1850) Plate 3, fig. E

Sampling stations: $1,11$.

Material examined: 7 specimens.

Occurrence: Live specimens were collected at a depth of 1-12 $\mathrm{m}$, in mud and among sea grass and algae.

36. Protothaca (Protocallithaca) adamsii (Reeve, 1863) Plate 3, fig. G

Sampling stations: $3,7,8,10$.

Material examined: 6 specimens.

Occurrence: Live specimens were collected at a depth of 22-56 m, and empty shells at 15-22 m, in mud and coarse sand.

Comments: P. adamsii (type species of Protocallithaca Nomura, 1937) is very similar to Protothaca Dall, 1902 in cardinal teeth characteristics and finely crenulated inner ventral margin, but its external shell sculpture resembles Callithaca Dall, 1902, and it is better to be assigned to the subgenus Protothaca (Protocallithaca) (Matsubara, 2009).

Family Myochamidae P.P. Carpenter, 1861

37. Myadora japonica Habe, 1950

Plate 3, fig. $\mathrm{H}$

\section{Sampling station: 5 .}

Material examined: 1 specimen.

Occurrence: An empty shell was taken at a depth of 43 $\mathrm{m}$, in mud.

\section{FAUNAL ANALYSIS}

A total of 37 species of bivalve mollusks were collected at 11 sampling stations in Ulsan Bay. Taking into account available literature data (Yi et al., 1982; Rho et al., 1997; Shin H.C. et al., 2001; Yoon S.-P. et al., 2009), the combined list of bivalves consists of 61 species, among which 8 taxa are indentified to genus or family level (Table 2). Comparison of species richness of bivalve molluscan faunas in various regions of the eastern and southern coasts of Korea shows that the richest areas are Goseong-gun in Gangwon Province and Yeongil Bay in Gyeongbuk Province, 85 and 98 species, respectively (Table 3). Bivalve faunas of various islands are noticeably poor, from 9 to 33 species, and even Geoje Island, a large island off the southeast coast, has only 45 reported species. In contrast, the Jeju Island bivalve fauna, though more subtropical than that of the continental coast of Korea, is very rich with 225 species recorded (Table 3). Such differences can be explained by insuffient attention given to the study of the regional or local molluscan faunas of Korea, a very shortsighted practice in light of rapid environmental changes, growth of urban areas, and increasing human pressure on coastal zones in the past decades. The entire South Korean coast of the East Sea (south to Busan) is inhabited by 312 species of bivalves (Lutaenko and Noseworthy, 2012).

We believe that bivalve molluscan fauna of Ulsan Bay may include up to 100 species and should not be poorer than that of Yeongil Bay. Additional collecting in Ulsan Bay is needed but, even with our limited material, we can trace some differences with other regions of Korea, and also faunal affinities. At least, 23 species found in Ulsan Bay are not known from Yeongil Bay (A. divaricata, B. trapezina, $S$. symmetrica, $M$. senhousia, $C$. decussata, $G$. coralliophaga, S. circumpicta, A. chinensis, $C$. lemniscata, T. tokunagai, C. toneana, F. hungerfordi, L. undulata, $M$. venulosus, $A$. vestalioides, $A$. abbreviatus, F. sowerbyi, D. penicillata, R. aspera, $P$. undulata, P. euglypta, P. mirabilis, L. boschasina). Whereas some of them can be doubtful literature records, others do not appear to inhabit the more northern areas of South Korea (D. penicillata, $B$. trapezina, A. abbreviatus, $R$. aspera, P. undulata). Distributional ranges of $M$. senhousia and $D$. penicillata in the entire East Sea are discontinuous: they are known from Peter the Great Bay in the north-western East Sea and are absent from mid-Primorye further north (Lutaenko and Noseworthy, 2012) but may be found alive in North Korea. They live only in shallow bays with summer warming sufficient for successful reproduction and 
Table 2. A list of species of bivalve mollusks from Ulsan Bay

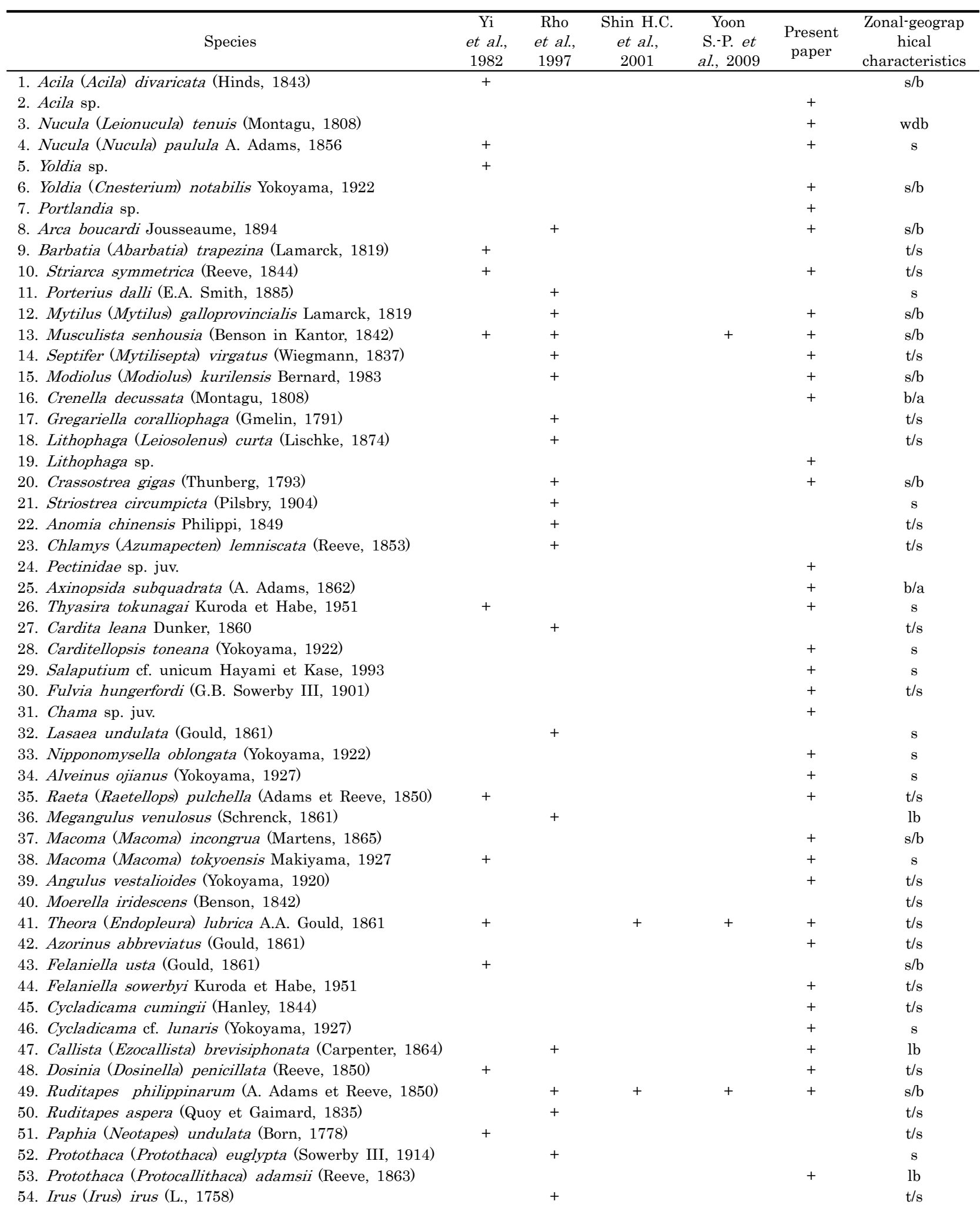




\begin{tabular}{|c|c|c|c|}
\hline 55. Irus sp. & + & & \\
\hline 56. Pseudoirus mirabilis Deshayes, 1853 & + & & $\mathrm{s}$ \\
\hline 57. Aspidopholas sp. & + & & \\
\hline 58. Hiatella orientalis (Yokoyama, 1920) & + & & $\mathrm{s} / \mathrm{b}$ \\
\hline 59. Myadora japonica Habe, 1950 & & + & $\mathrm{s}$ \\
\hline 60. Entodesma navicula (A. Adams et Reeve, 1850) & + & & $\mathrm{wdb}$ \\
\hline 61. Laternula boschasina (Reeve, 1860) & + & & $\mathrm{t} / \mathrm{s}$ \\
\hline
\end{tabular}

Abbreviations: t/s - tropical-subtropical species; s - subtropical species; s/b - subtropical-boreal (mostly subtropical-lowboreal) species; lb - lowboreal species; b/a - boreal-arctic species (including widely distributed boreal-arctic); $\mathbf{w d b}+\mathbf{c b}$ - widely distributed boreal + circumboreal species.

Notes: Barbatia (Abarbatia) trapezina (Lamarck, 1819) was listed as Abarbatia lima (Yi et al., 1982), a synonym of the former species; Striarca symmetrica (Reeve, 1844) was listed as Arcopsis symmetrica (Yi et al., 1982); Mytilus (Mytilus) galloprovincialis Lamarck, 1819 was listed as Mytilus edulis in Rho et al. (1997); Modiolus (Modiolus) kurilensis Bernard, 1983 was listed as Modiolus modiolus difficilis in Rho et al. (1997), a synonym of the former species; Striostrea circumpicta (Pilsbry, 1904) was listed as Ostrea circumpicta in Rho et al. (1997); Theora (Endopleura) lubrica A.A. Gould, 1861 was listed as Theora lata in Yi et al. (1982); Ruditapes aspera (Quoy et Gaimard, 1835) was listed as Ruditapes variegatus in Rho et al. (1997), a synonym of the former species; Irus (Irus) irus (L., 1758) was listed as Irus macrophyllus in Rho et al. (1997), a possible synomym of the former species; Entodesma navicula (A. Adams et Reeve, 1850) was listed as Agriodesma navicula in Rho et al. (1997); more information on taxonomy can be found in Huber (2010) and Lutaenko and Noseworthy (2012).

Table 3. Species richness of bivalve molluscan faunas in various regions of the eastern and southern coasts of Korea

\begin{tabular}{ccc}
\hline Region & Number of species & Reference \\
\hline Goseong-gun (Gangwon Province) & 85 & Park T.S. et al. (2011) \\
Yeongil Bay & 98 & Lutaenko et al. (2003; 2006) \\
Ulsan Bay & 61 & Present paper \\
Geoje Island & 45 & Rho et al. (1998) \\
$\begin{array}{c}\text { Tokdong (Masan Bay), Charando and } \\
\text { Dolsan Islan, South Sea of Korea }\end{array}$ & 27 & Choe B.L. et al. (1995) \\
$\begin{array}{c}\text { Komundo, Taesambudo, Sangpaekdo } \\
\text { islands (South Sea of Korea) }\end{array}$ & 9 & Kim H.S. and Shin M.K. (1986) \\
$\begin{array}{c}\text { Jindo Island (south-western Korea) } \\
\text { Around Hwawon Peninsula } \\
\quad \text { (south-western Korea) }\end{array}$ & 33 & Kim H.S. and Kim I.-H. (1985) \\
$\quad \begin{array}{l}\text { Eastern coast of South Korea } \\
\text { (south to Busan) } \\
\text { Jeju Island }\end{array}$ & 37 & Kil H.J. et al. (2005) \\
$\quad 312$ & 225 & Lee Y.G. (1997b); Lee Y.G. and Choi J.M. (2007); \\
including shells from the Holocene deposits
\end{tabular}

with muddy bottoms, i.e., typical embayments. In the northern East Sea they are relics of the mid-Holocene climatic optimum (Lutaenko, 1993; Lutaenko and Noseworthy, 2014).

Although the Ulsan Bay bivalve fauna is insufficiently known, we have undertaken an analysis of its biogeographical structure following the zonal-geographical (zonal-biogeographical) approach widely used in the Russian literature (see for extended discussion: Lutaenko and Noseworthy (2014)). We recognize six major zonal-geographical groups: 1. tropical-subtropical (distributed southward to the Philippines, Vietnam, and Indonesia); 2. subtropical (distributed southward to Taiwan and the northern part of the South China Sea); 3. subtropical-lowboreal (limited both to subtropical seas and the East Sea, southeastern Sakhalin, and the southern Kuril Islands); 4. lowboreal (limited to the East Sea from Peter the Great Bay, northern Korea, and northern Honshu to Aniva and Terpenya bays, southwestern Sakhalin, and the southern Kurile Islands); 5. widely distributed boreal (limited to the East Sea and 


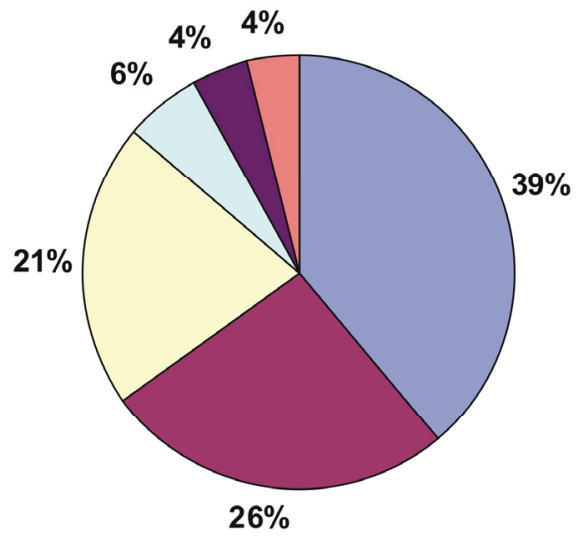

$\square$ t/s $\square$ s $\square$ s/b $\square$ lb $\square$ wdb $\square$ b/a

Fig. 2. Zonal-biogeographical composition of the Ulsan Bay bivalve fauna (abbreviations: t/s - tropical-subtropical species; s - subtropical species; s/b - subtropical-boreal (mostly subtropical-lowboreal) species; lb - lowboreal species; b/a - boreal-arctic species; wdb - widely distributed boreal + circumboreal species).

Hokkaido to the Bering Strait, along the Asian coast, and along the northern American coast southward to California), and circumboreal (limited mainly to temperate latitudes, both in the Atlantic and Pacific Oceans, but also partly to subtropical and arctic zones); 6. boreal-arctic (limited to both the temperate zone of the Pacific Ocean and the Arctic, and partly to the temperate Atlantic). We checked the geographical distribution of many species using numerous literature sources, and unified zonal-geographical characteristics are given for each species in our catalogue (Lutaenko and Noseworthy, 2012).

The bivalve fauna in Ulsan Bay is dominated by warm-water mollusks: tropical-subtropical (21 species, or $39 \%$ of the total species number), subtropical (14 species, or 26\%) and subtropical-boreal (mostly subtropical-lowboreal) (11 species, 21\%), totalling 86\% (Fig. 2). There are also 2 boreal-arctic and several boreal species; therefore, the fauna can be regarded as subtropical with an admixture of boreal and boreal-arctic species (14\%). However, the share of wholly subtropical species may increase with more faunal research and a more lengthy list of species. A remarkable feature of the Ulsan Bay fauna is the presence of tropical-subtropical species not found in Yeongil Bay but common in the tidal flats and shallow waters of the Yellow Sea and the southern part of Korea. Thus, even the occurrence of upwelling cold waters in summer around Ulsan does not prevent warm-water mollusks from living in Ulsan Bay. It seems that the area between Yeongil and Ulsan bays is an important intermediate zone where the two faunas meet. We proposed that there is a transition zone marking a decline of cold-water bivalve mollusks and a significant increase of warm-water species between Yeongil Bay and Busan on the continental coast of the East Sea (Lutaenko and Noseworthy, 2014). Similarly, there is a corresponding zone between the Noto Peninsula and Tsugaru Strait in the eastern part of the Sea which is comparable to the earlier "discontinuity belt" of abrupt change in the number of southern elements of Nishimura (1965). This belt marks the boundary between subtropical and boreal zones in the East Sea, or Warm-Temperate and Cold-Temperate zones according to the concept of Briggs (2007).

Y.G. Lee (1997a) studied the Quaternary environments, sea-level changes, and molluscan thanatocoenoses in the continental shelf off Ulsan. At a depth range of 45-158 m (but mostly below $100 \mathrm{~m}$ ), this author encountered 72 species of Bivalvia and established 17 molluscan assemblages. Among them, the author enumerated species belonging to some genera not found in our shallow-water survey (e.g., Nuculana, Neilonella, Limopsis, Glycymeris, Polynemamussium, Cyclocardia, Trapezium, Tridonta (= Astarte), Cadella, Anisocorbula, etc.). Part of this complex belongs to the last glacial period of low-stand sea level, and it reflects tidal flat embaymental conditions (e.g., A. boucardi, Nipponarca bistrigata (Dunker, 1866), Trapezium bicarinatum (Schumacher, 1817), Trapezium liratum (Reeve, 1843), Moerella jedoensis (Lischke, 1872), F. usta) but these assemblages also include indicator fossils of the Late Pliocene-Pleistocene formations (e.g., Mizuhopecten tokyoensis hokurikuensis (Akiyama, 1962)). Thus, this Quaternary complex can be considered to be an initial post-glacial and early-Holocene transgression 
assemblage of bivalve mollusks having a mixed coldand warm-water character and formed at the beginning of the development of the Recent East Sea molluscan fauna. Similar shelf deposits around Tsushima contain shells with radiocarbon ages as old as ca. 14000-15000 years BP (Lee Y.G., 2005). This fauna can be compared with those described by G.A. Evseev (1981) for the early stages of the post-glacial transgression in the north-western East Sea; the latter typically includes more cold-water species (Pododesmus macrochisma (Deshayes, 1839), Clinocardium ciliatum (Fabricius, 1780), Callista brevisiphonata (Carpenter, 1864), Liocyma fluctuosum (Gould, 1841), Macoma middendorffi Dall, 1884, Macoma lama Bartsch, 1929, Mactromeris polynyma (Stimpson, 1860), etc.). However, the south-western East Sea Late Quaternary molluscan assemblages contain much more warm-water faunal elements. About 15000 ago, Korean shorelines extended seaward by more than $100 \mathrm{~km}$ as sea level was lower than the present-day, about $120 \mathrm{~m}$ deep (Lee Y.G. et al., 2008). Remnants of this post-glacial fauna still exist on the shelf and in embayments in South Korea.

The Ulsan Bay bivalve fauna clearly exhibits wider depth ranges of warm-water bivalves as compared to northern regions of the East Sea (Table 4); this can be explained by the influence of warm currents on the lower subtidal zone of this part of the Sea. Whereas warm-water species in Peter the Great Bay, in the north-western East Sea, prefer the upper subtidal zone, cold-water species concentrate deeper. For instance, in Ussuriysky Bay, an overwhelming majority of subtropical and subtropical-lowboreal mollusks inhabits the 0-30 $\mathrm{m}$ depth range but are rare below $31 \mathrm{~m}$; tropical-subtropical species are not recorded deeper than $61 \mathrm{~m}$. In contrast, the number of boreal-arctic species increases with depth. The same trend is observed for the molluscan faunas of Possjet and Amursky bays (Lutaenko and Noseworthy, 2014). In Possjet Bay, open and semi-enclosed areas are clearly differentiated by their biogeographic composition (Golikov and Scarlato, 1967; Scarlato, 1981), and warm-water taxa predominate in semi-enclosed inlets and inner, shallow parts of the bay. The proportion of subtropical and subtropical-lowboreal species in semi-enclosed inlets reaches $46 \%$, while in open areas it is only $12 \%$. This pattern is connected with the heterogeneity of summer temperatures in bays, which allows eurythermal, warm-water, taxa to concentrate in semi-enclosed inlets and inner parts under favourable conditions for spawning.

The same trend of the existence of wider bathymetric ranges of warm-water bivalves is observed along the eastern coast of the East Sea, on the coast of Japan, where the influence of the warm Tsushima Current is very strong (Table 4). A. boucardi does not live in the northern part of the sea deeper than $18 \mathrm{~m}$

Table 4. Bathymetric ranges $(\mathrm{m})$ of some warm-water bivalve mollusks found in Ulsan Bay in comparison with other areas of East Sea

\begin{tabular}{|c|c|c|c|c|c|c|}
\hline Species & $\begin{array}{c}\text { Ulsan } \\
\text { Bay }\end{array}$ & $\begin{array}{l}\text { Yeongil } \\
\text { Bay }\end{array}$ & $\begin{array}{l}\text { Niigata } \\
\text { Pref. }\end{array}$ & $\begin{array}{l}\text { Ishikawa } \\
\text { Pref. }\end{array}$ & $\begin{array}{c}\text { Wakasa Bay and } \\
\text { Hyogo Pref. }\end{array}$ & $\begin{array}{l}\text { Peter the Great } \\
\text { Bay and Primorye }\end{array}$ \\
\hline Arca boucardi & 43 & $6.5^{-30}$ & $11-210$ & $20-100$ & $41-139$ & $0-18$ \\
\hline Musculista senhousia & 55 & & & & & $0-6$ \\
\hline Alveinus ojianus & $15-43$ & $6.5^{-35.5}$ & & & & $0-74$ \\
\hline Raeta pulchella & $22-55$ & $6.5^{-30}$ & 5-102 & & $39-62$ & $4.5^{-39}$ \\
\hline Macoma incongrua & 43 & & & $40-106$ & & $0-30$ \\
\hline Macoma tokyoensis & 43 & $12-21$ & & & & $2-12$ \\
\hline Theora lubrica & $1-55$ & $8.5^{-28}$ & $34-56$ & & & $3-25$ \\
\hline Dosinia penicillata & $22-43$ & & & & & $2^{-7}$ \\
\hline Protothaca adamsii & $15^{-56}$ & $6.5^{-52}$ & & & $87-161$ & $1-45$ \\
\hline
\end{tabular}

Notes: Yeongil Bay, Korea (Lutaenko et al., 2003); Niigata Pref. (including Sado Isl.; eastern East Sea) (Ito, 1978, 1985, 1989); Ishikawa Prefecture (Ito et al., 1986); Wakasa Bay and Hyogo Prefecture (eastern East Sea) (Ito, 1967, 1990); Peter the Great Bay and Primorye (north-western East Sea) (Scarlato, 1981; Lutaenko, 1999; 2003; 2006) 
while it is found on the Japan coast as deep as $210 \mathrm{~m}$, and in Ulsan Bay at a depth of $43 \mathrm{~m}$. D. penicillata, a relic of the mid-Holocene warming in Peter the Great Bay, lives there only in semi-enclosed bays and not deeper than $7 \mathrm{~m}$, but it is found at a depth of $22-43 \mathrm{~m}$ in Ulsan Bay. In Japan $M$. incongrua has a depth range of $106 \mathrm{~m}$, and in Ulsan Bay to $43 \mathrm{~m}$, while it occurs at a range of $0-30 \mathrm{~m}$ in the Russian part of the sea. This important biogeographic phenomenon can be regarded as the displacement of warm-water species into the upper subtidal zone in the high-latitude margin of their range, whereas the occurrence of cold-water species at greater depths in the low-latitude margin of their range, quite common in temperate latitudes, is called "submergence" (Dodd and Stanton, 1981).

The abundance of bottom animals, including bivalve mollusks, and the structure of bottom communities in Ulsan Bay have been studied by a number of researchers (Yi et al., 1982; Rho et al., 1997; Shin H.C. et al., 2001; Yoon S.-P. et al., 2009). In the early $1980 \mathrm{~s}$, five species were found to be dominant and common in Ulsan Bay: T. lubrica, M. senhousia, $M$. tokyoensis, N. paulula, R. pulchella (Yi et al., 1982). Intertidally and partly subtidally, $M$. galloprovincialis, C. gigas, S. virgatus, L. undulata and O. circumpicta were common (Rho et al., 1997). Later, $R$. philippinarum with a density of up to 86 ind. $/ \mathrm{m}^{2}$ and T. lubrica with a density up to 9 ind. $/ \mathrm{m}^{2}$ were collected in 1997, both found mostly in the estuary of the Taehwa River. In 2006 three species were dominant: T. lubrica, with an average density varying from month to month of $148,97,221$ and $227 \mathrm{ind} . / \mathrm{m}^{2}$ in February, May, August and November, respectively, $R$. philippinarum with 3034 ind. $/ \mathrm{m}^{2}$ in November, and $M$. senhousia with 223 ind./ $\mathrm{m}^{2}$ in November (Yoon S.-P. et al., 2009). According to our study, the most frequently encountered species was $N$. tenuis, with 579 living specimens at 7 (out of 11) stations. Other frequently found species were $T$. lubrica (104 specimens, 8 stations), A. ojianus (81 specimens, 5 stations), A. subquadrata (46 specimens, 8 stations), $R$. pulchella (34 specimens, 5 stations), and Y. notabilis (27 specimens, 6 stations). Some of these species are common in muddy bottom communities in shallow embayments in Korea: T. lubrica in Masan, Aenggang, Yoja and Chinhae bays; $R$. pulchella in Masan and Chinhae bays; A. ojianus in Aenggang Bay and in the Gangneung area (see Table 3 in: Lutaenko et al. (2006)). T. fragilis is considered as indicative of organic pollution (Hong et al., 1994). In Chinhae Bay, two peaks of spat settlement were observed, one in summer and another in winter, with a maximum in summer; the population density is highest at the mouth of the bay, up to 2116 ind. $/ \mathrm{m}^{2}$ in summer, but it rapidly declined in the fall after mass mortality (Lim et al., 1995). T. lubrica and R. pulchella are adapted to extreme environments and are often found on black deoxygenated mud where the bottom water lacks dissolved oxygen in the summer stagnation period (Habe, 1956). The formation of such populations exhibits a cyclic character, and juveniles are recruited several times during the stratification period. $T$. fragilis is a short-lived species; however, in the Seto Inland Sea most of the juveniles found at hypoxic stations died out immediately after settlement and never grew to the adult size (Kagawa, 1986). In Hakata Bay, northern Kyushu, the spatial dynamics of populations of $T$. fragilis and $M$. senhousia can differ greatly depending on the season. The center of mollusk distribution shifts from the inner waters of the bay to the central waters during the summer stratification period when dissolved oxygen of the bottom water diminishes; the center returns to the inner waters when dissolved oxygen increases (Hamano et al., 1986). In the northern East Sea, $T$. fragilis plays a significant role in soft-bottom communities of semi-enclosed inlets in Possjet Bay with a density of up to $140 \mathrm{ind} . / \mathrm{m}^{2}$ (Golikov and Scarlato, 1967), and is also very abundant in muddy substrate in the innermost parts of Amursky and Nakhodka Bays (Lutaenko, 1999; 2003).

\section{ACKNOWLEDGEMENTS}

The author is very grateful to Dr. Lee Eui-Hyeong (formerly, Korea University, Seoul) and Dr. Eugene I. Schornikov (A.V. Zhirmunsky Institute of Marine Biology, FEB RAS, Vladivostok) for the invitation to 
take part in the coastal expedition in August 1997. Dr. Je Jong-Geel and Dr. Shin Sang-Ho generously supported this project and helped much with fieldwork. Ronald Noseworthy (Jeju National University, Jeju) kindly improved the draft of this paper and provided many useful comments. Prof. Kwang-Sik Choi (Jeju National University) kindly provided some Korean paper. Mrs. Irina E. Volvenko (Zoological Museum, Far Eastern Federal University) prepared the photographs.

\section{REFERENCES}

Adams, A. (1862) On some new species of the acephalous Mollusca from the Sea of Japan. Annals and Magazine of Natural History, Series 3, 9: 223-230.

Briggs, J.C. (2007) Marine longitudinal biodiversity: causes and conservation. Diversity and Distributions, 13: 544-555.

Carter, J.G., Altaba, C.R., Anderson, L.C., Araujo, R., Biakov, A.S., Bogan, A.E., Campbell, D.C., Campbell, M., Chen, J.-H., Cope, J.C.W., Delvene, G., Dijkstra, H.H., Fang, Z.-J., Gardner, R.N., Gavrilova, V.A., Goncharova, I.A., Harries, P.J., Hartman, J.H., Hautmann, M., Walter, R. Hoeh, W.R., Hylleberg, J., Jiang, B.-Y., Johnston, P., Kirkendale, L., Kleemann, K., Koppka, J., K-i-, J., Machado, D., Malchus, N., Marquez-Aliaga, A., Masse, J.-P., McRoberts, C.A., Middelfart, P.U., Mitchell, S., Nevesskaja, L.A., Ozer, S., Pojeta, J., Jr., Polubotko, I.V., Pons, J.M., Popov, S., Sanchez, T., Sartori, A.F., Scott, R.W., Sey, I.I., Signorelli, J.H., Silantiev, V.V., Skelton, P.W., Steuber, T., Waterhouse, J.B., Wingard, G.L. and Yancey, T. (2011) A synoptical classification of the Bivalvia. Paleontological Contributions, 4: 1-47.

Choe, B.L., Park, J.-K. and Lee, J.R. (1995) Analyses of macrozoobenthic communities at the inter- and subtidal zones of Tokdong, Charando and Isudo islands along southern coast of Korea. Korean Journal of Malacology, 11: 35-50. [in Korean with English abstract].

Coan, E.V., Scott, P.V. and Bernard, F.R. (2000) Bivalve seashells of western North America. Santa Barbara Museum of Natural History Monographs, 2: 1-764.

Coan, E.V. and Valentich-Scott, P. (2012) Bivalve seashells of tropical west America. Marine bivalve mollusks from Baja California to northern Per-. Part 1. Santa Barbara Museum of Natural History Monographs, 6 (Studies in Biodiversity, 4): 1-598.

Dulenina, P.A. (2013) The species composition of bivalve mollusks in the western part of Tatarsky Strait (Sea of Japan). Bulletin of the Russian Far East Malacological Society, 17: 27-78. [in Russian with English abstract].

Evseev, G.A. (1981) Communities of Bivalve Mollusks in
Postglacial Deposits of Shelf of the Sea of Japan. 160 pp. Nauka, Moscow. [in Russian].

Fischer-Piette, E. and Delmas, D. (1967) R-vision des mollusques lamellibranches du genre Dosinia Scopoli. Mémoires du Muséum National d'Histoire Naturelle. Nouvelle Série. Série A: Zoologie, 47: 1-91.

Golikov, A.N. and Scarlato, O.A. (1967) Molluscs of the Possjet Bay (the Sea of Japan) and their ecology. Proceedings of the Zoological Institute, USSR Academy of Sciences, 42: 5-154. [in Russian].

Habe, T. (1956b) Studies on the shell remains in bays. Contribution to Physiology and Ecology, Kyoto University, 77: 1-31. [in Japanese with English abstract].

Habe, T. (1977) Systematics of Mollusca in Japan. Bivalvia and Scaphopoda. 372 pp. Hokuryukan, Tokyo. [in Japanese].

Hamano, T., Kouya, T., Shimoyama, S. and Matsuura, S. (1986) The dynamics of the molluscan community in the soft bottom of Hakata Bay, Japan, with special reference to the summer stratification period. Benthos Research, 29: 1-8. [in Japanese with English abstract].

Higo, S., Callomon, P. and Goto, Y. (1999) Catalogue and Bibliography of the Marine Shell-bearing Mollusca of Japan. 749 pp. Elle Scientific Publications, Osaka.

Hong, J.-S., Seo, I.-S., Yoo, J.-W. and Jung, R.-H. (1994) Soft-bottom benthic communities in North Port, Inchon, Korea. Nature Conservation, 88: 34-50.

Huber, M. (2010) Compendium of Bivalves. A Full-Color Guide to 3,300 of the World's Marine Bivalves. A Status on Bivalvia after 250 Years of Research. 901 pp. ConchBooks, Hackenheim.

Ito, K. (1967) A catalogue of the marine molluscan shell-fish collected on the coast of and off Tajima, Hyogo Prefecture. Bulletin of the Japan Sea Regional Fisheries Research Laboratory, 18: 39-91. [in Japanese with English abstract].

Ito, K. (1978) The distribution of shell remains in the Mano Bay of Sado Island and its vicinity. Bulletin of the Japan Sea Regional Fisheries Research Laboratory, 29: 201-227. [in Japanese with English abstract].

Ito, K. (1985) Distribution of the molluscan shells in the surrounding areas of Sado and Awa Is, Niigata Prefecture. Bulletin of the Japan Sea Regional Fisheries Research Laboratory, 35: 23-127. [in Japanese with English abstract].

Ito, K. (1989) Distribution of molluscan shells in the coastal areas of Chuetsu, Kaetsu and Sado Island, Niigata Prefecture, Japan. Bulletin of the Japan Sea Regional Fisheries Research Laboratory, 39: 37-133. [in Japanese with English abstract].

Ito, K. (1990) Distribution of molluscan shells in Wakasa Bay, Japan Sea. Bulletin of the Japan Sea National Fisheries Research Institute, 40: 79-211. [in Japanese with English abstract]. 
Ito, K., Matano, Y., Yamada, Y., and Igarashi, S. (1986) Shell species caught [by] S/S Rokko-Maru off the coast [of] Ishikawa Prefecture. Bulletin of the Ishikawa Prefectural Fisheries Experimental Station, 4: 1-179. [in Japanese with English abstract].

Jacobs, A.J. (2011) Ulsan, South Korea: a global and nested 'Great' Industrial City. Open Urban Studies Journal, 4: 8-20.

Je, J.-G. (1989) Korean names of molluscs in Korea. Korean Journal of Malacology, Suppl., 1: 1-91. [in Korean].

Je, J.-G., Chang, M. and Park, H.-S. (1991) Distribution of benthic molluscs in soft bottom of the Southern Sea of Korea. Korean Journal of Malacology, 7: 30-48. [in Korean with English abstract].

Kafanov, A.I. (1991) Shelf and Continental Slope Bivalve Molluscs of the Northern Pacific Ocean: a Check-list. 198 pp. Far East Branch, USSR Academy of Sciences, Vladivostok. [in Russian].

Kafanov, A.I. and Lutaenko, K.A. (1997) New data on the bivalve mollusc fauna of the North Pacific Ocean. 3. On some species of the subfamily Dosiniinae (Veneridae). Ruthenica. Russian Malacological Journal, 7: 149-153. [in Russian with English abstract].

Kagawa, T. (1986) Fluctuation patterns of macrobenthic fauna during the stratification period in the eastern part of Hiuchi-Nada, Seto Inland Sea. Benthos Research, 29: 9-15. [in Japanese with English abstract].

Kamenev, G.M. (2013) Species composition and distribution of bivalves in bathyal and abyssal depths of the Sea of Japan. Deep-Sea Research II, 86-87: 124-139.

Kang, Y.Q. and Jin, M.-S. (1984a) Annual variation of salinity in the neighbouring seas of Korea. Journal of the Oceanological Society of Korea, 19: 105-110.

Kang, Y.Q. and Jin, M.-S. (1984b) Seasonal variation of surface temperatures in the neighbouring seas of Korea. Journal of the Oceanological Society of Korea, 19: 31-35.

Khim, J.S., Lee, K.T., Kannan, K., Villeneuve, D.L., Giesy, J.P. and Koh, C.H. (2001) Trace organic contaminants in sediment and water from Ulsan Bay and its vicinity, Korea. Archives of Environmental Contamination and Toxicology, 40: 141-150.

Kil, H.J., Yoon, S.H., Kim, W., Choe, B.L., Sohn, H.J. and Park, J.-K. (2005) Faunistic investigation for marine mollusks in Jindo Island. Korean Journal of Systematic Zoology, Special Issue, 5: 29-46.

Kim, C.H. and Kim, K. (1983) Characteristics and origin of the cold water mass along the east coast of Korea. Journal of the Oceanological Society of Korea, 18(1): 73-83. [in Korean with English abstract].

Kim, H.S. and Kim, I.-H. (1985) Marine invertebrate fauna of Komundo I., Taesambudo I. and Sangpaekdo I. Report on the Survey of Natural Environment in Korea, 4: 181-206. [in Korean with
English abstract].

Kim, H.S. and Shin, M.K. (1986) Marine mollusks and arthropods from Dolsan Island in South Sea of Korea. Nature Conservation, 55: 31-40. [in Korean with English abstract].

Kuroda, T. and Habe, T. (1952) Check List and Bibliography of the Recent Marine Mollusca of Japan. 210 pp. L.W. Stach, Tokyo.

Kussakin, O.G. (1990) Biogeography of isopod crustaceans in the boreal Pacific. Bulletin of Marine Science, 46: 620-639.

Kwon, O.K., Park, G.M. and Lee, J.S. (1993) Coloured Shells of Korea. 445 pp. Academy Publ. Co., Seoul. [In Korean].

Kwon, O.K., Min, D.K., Lee, J.R., Lee, J.S., Je, J.G. and Choe, B.L. (2001) Korean Mollusks with Color Illustrations. 332 pp. Hanguel, Busan. [In Korean].

Kwon, Y.W. and Lee, J.D. (Eds.). (2010) The Geography of Korea. 432 pp. National Geographic Information Institute (NGII), Suwon.

Lee, E.-H., Huh, M. and Schornikov, E.I. (2000) Ostracod fauna from the East Sea coast of Korea and their distribution - preliminary study on Ostracoda as an indicator of water pollution. Journal of the Geological Society of Korea, 36: 435-472. [in Korean with English abstract].

Lee, J.C., Kim, D.H. and Kim, J.-C. (2003) Observations of coastal upwelling at Ulsan in summer [of] 1997. Journal of the Korean Society of Oceanography, 38: 122-134.

Lee, J.C. and Na, J.Y. (1985) Structure of upwelling off the southeast coast of Korea. Journal of the Oceanological Society of Korea, 20: 6-19.

Lee, J.-S. and Min, D.-K. (2002) A catalogue of molluscan fauna in Korea. Korean Journal of Malacology, 18: 93-217. [in Korean with English abstract].

Lee, K.-B. (1978) Study on the coastal cold water near Ulsan. Journal of the Oceanological Society of Korea, 13: $5-10$.

Lee, K.W., Lee, D.S., Lee, S.H. and Matsumoto, E. (1988) History of heavy metal pollution in Masan and Ulsan Bay sediments. Ocean Research, 10: 7-13.

Lee, T. and Kim, I.-N. (2003) Chemical imprint of the upwelled waters off the coast of the southern East Sea of Korea. Journal of the Korean Society of Oceanography, 38: 101-110.

Lee, Y.G. (1997a) The Quaternary paleoenvironment and molluscan thanatocoenoses characteristics in the continental shelf off Ulsan, southeastern of Korea. Journal of the Paleontological Society of Korea, 13: 103-118. [in Korean with English abstract].

Lee, Y.G. (1997b) Characteristic of molluscan thanatocoenoses distributed around Hwawon Peninsula in southwestern coast, Korea. Journal of the Paleontological Society of Korea, 13: 1-20. [in Korean with English abstract].

Lee, Y.G. (2005) Post-Last Glacial sea-level change and 
time-averaging appeared from the molluscan thanatocoenses in the Southern Sea of Korea. Journal of the Korean Earth Science Society, 36: 541-550. [in Korean with English abstract].

Lee, Y.G. and Choi, J.M. (2007) Holocene paleoenvironment and paleogeography change appeared from the molluscan thanatocoenoses of the Korean southwest sea. Journal of the Paleontological Society of Korea, 23: 49-71. [in Korean with English abstract].

Lee, Y.G., Choi, J.M. and Oertel, G.F. (2008) Postglacial sea-level change of the Korean Southern Sea shelf. Journal of Coastal Research, 24(4C suppl.): 118-132.

Lim, H.-S., Hong, J.-S. and Je, J.-G. (1995) Abundance and distribution pattern of the semelid bivalve, Theora fragilis A. Adams in Chinhae Bay, Korea. Korean Journal of Malacology, 11: 21-34.

Lutaenko, K.A. (1993). Climatic optimum during the Holocene and the distribution of warm-water mollusks in the Sea of Japan. Palaeogeography, Palaeoclimatology, Palaeoecology, 102: 273-281.

Lutaenko, K.A. (1999) Additional data on the fauna of bivalve mollusks of the Russian continental coast of the Sea of Japan: middle Primorye and Nakhodka Bay. Publications of the Seto Marine Biological Laboratory, 38: 255-286.

Lutaenko, K.A. (2003) Bivalve molluscan fauna of Amursky Bay (Sea of Japan/East Sea) and adjacent areas. Part 2. Families Trapezidae - Periplomatidae. Ecological and biogeographical characteristics of the fauna. Bulletin of the Russian Far East Malacological Society, 7: 5-84. [in Russian].

Lutaenko, K.A. (2006) Bivalve mollusks of Ussuriysky Bay (Sea of Japan). Part 2. Bulletin of the Russian Far East Malacological Society, 10: 46-66.

Lutaenko, K.A., Je, J.-G. and Shin, S.-H. (2002) Report on bivalve mollusks from beach death assemblages in Gangwon and Gyeongsangbuk Provinces, Korea (East Sea). Korean Journal of Malacology, 18: 27-40.

Lutaenko, K.A., Je, J.-G. and Shin, S.-H. (2003) Bivalve mollusks in Yeongil Bay, Korea. 1. Introductory part and annotated list of species. Ocean and Polar Research, 25: 155-182.

Lutaenko, K.A., Je, J.-G. and Shin, S.-H. (2006) Bivalve mollusks in Yeongil Bay, Korea. 2. Faunal analysis. Korean Journal of Malacology, 22: 63-86.

Lutaenko, K.A. and Noseworthy, R.G. (2012) Catalogue of the Living Bivalvia of the Continental Coast of the Sea of Japan (East Sea). 247 pp. Dalnauka, Vladivostok.

Lutaenko, K.A. and Noseworthy, R.G. (2014) Biodiversity and biogeographical patterns of bivalve mollusks in the Sea of Japan. In: Marine Biodiversity and Ecosystem Dynamics of the North-Western Pacific Ocean (ed. by Sun, S., Adrianov, A.V., Lutaenko, K.A., Sun, X.). Science Press, Beijing. P. 159-187.

Matsubara, T. (2009) Neogene Mollusca from the Yunokogawa Formation in the Shimokita Peninsula, northeast Japan. Paleontological Research, 13: 173-192.

Min, D.-K., Lee, J.-S., Koh, D.-B. and Je, J.-G. (2004) Mollusks in Korea. 566 pp. Min Molluscan Research Institute, Seoul. [In Korean].

Nishimura, S. (1965) The zoogeographical aspects of the Japan Sea. Part I. Publications of the Seto Marine Biological Laboratory, 13(1): P. 35-79.

Nomura, S. (1932) Mollusca from the raised beach deposits of the Kwant- region. Science Reports of the Tohoku Imperial University, Series 2, 15: 67-147.

Noseworthy, R.G., Lim, N.-R. and Choi, K.-S. (2007) Catalogue of the mollusks of Jeju Island, South Korea. Korean Journal of Malacology, 23: 65-104.

Oyama, K. (1980) Revision of Matajiro Yokoyama's type Mollusca from the Tertiary and Quaternary of the Kanto area. Palaeontological Society of Japan, Special Paper, 17: 1-148.

Park, T.S., Ye, E., Kil, H.J., Lee, S.G. and Yi, C.H. (2011) A checklist of marine invertebtrates (polychaetes, amphipods, decapods and molluscs) of Goseong-gun, Gangwon-do area. Journal of Korean Nature, 4: 229-253.

Rho, B.J., Choe, B.L., Lee J.R., Kil H.J. (1998) Malacofauna of Geojedo Island, Korea. Korean Journal of Systematic Zoology, 14: 257-278. [in Korean with English abstract].

Rho, B.J., Choe, B.L., Song, J.-I., Park, K.S., Lee, I.-S. and Park, J.-K. (1997) An analysis of invertebrate community at the tidal and subtidal zone in Onsan Bay with regard to the effect of pollution. Korean Journal of Environmental Biology, 15: 79-88. [in Korean with English abstract].

Scarlato, O.A. (1960) Bivalve mollusks of the Far Eastern seas (Order Dysodonta). Guide-Books on the Fauna of the USSR Published by the Zoological Institute, USSR Academy of Sciences, 71: 1-150. [In Russian].

Scarlato, O.A. (1981) Bivalve mollusks of temperate latitudes of the western portion of the Pacific Ocean. Guide-Books on the Fauna of the USSR Published by the Zoological Institute, USSR Academy of Sciences, 126: 1-479. [In Russian].

Shin, H.C. and Koh, C.-H. (1993) Distribution and abundance of ophiuroids on the continental shelf and slope of the East Sea (southwestern Sea of Japan), Korea. Marine Biology, 115: 393-399.

Szefer, P., Kim, B.-S., Kim, C.-K., Kim, E.-H. and Lee, C.-B. (2004) Distribution and coassociations of trace elements in soft tissue and byssus of Mytilus galloprovincialis relative to the surrounding seawater and suspended matter of the southern part of the Korean Peninsula. Environmental Pollution, 129: 209-228.

Wong, H.W. (2009) The Mactridae (Mollusca: Bivalvia) of East Coast Park, Singapore. Nature in Singapore, 2: 283-296.

Xu, F. (1984) Preliminary study on the Protobranchia 
(Mollusca) from the shallow waters of China. II. Nuculidae. Studia Marina Sinica, 22: 179-188. [in Chinese with English abstract].

Xu, F. (1999) Fauna Sinica. Phylum Mollusca. Class Bivalvia:

Subclasses Protobranchia

and Anomalodesmata. 237 pp. Science Press, Beijing. [in Chinese with English abstract].

Yi, S.K., Hong, J.-S., and Lee, J.H. (1982) A study on the subtidal benthic community in Ulsan Bay, Korea. Bulletin of Korea Ocean Research and Development Institute, 4: 17-26.

Yokoyama, M. (1922) Fossils from the upper Musashino of Kazusa and Shimosa. Journal of the College of Science, Imperial University of Tokyo, 44: 1-200.

Yokoyama, M. (1926) Fossil shells from Sado. Journal of the Faculty of Science, Imperial University of Tokyo, Section 2, 1: 249-312.

Yoon, S.-P., Jung, R.-H., Kim, Y.-J., Kim, S.-G., Choi, M.-K., Lee, W.-C., Oh, H.-T. and Hong, S.-J. (2009) Macrobenthic community structure along the environmental gradients of Ulsan Bay, Korea. The Sea (Journal of the Korean Society of Oceanography), 14: 102-117. [in Korean with English abstract]. 


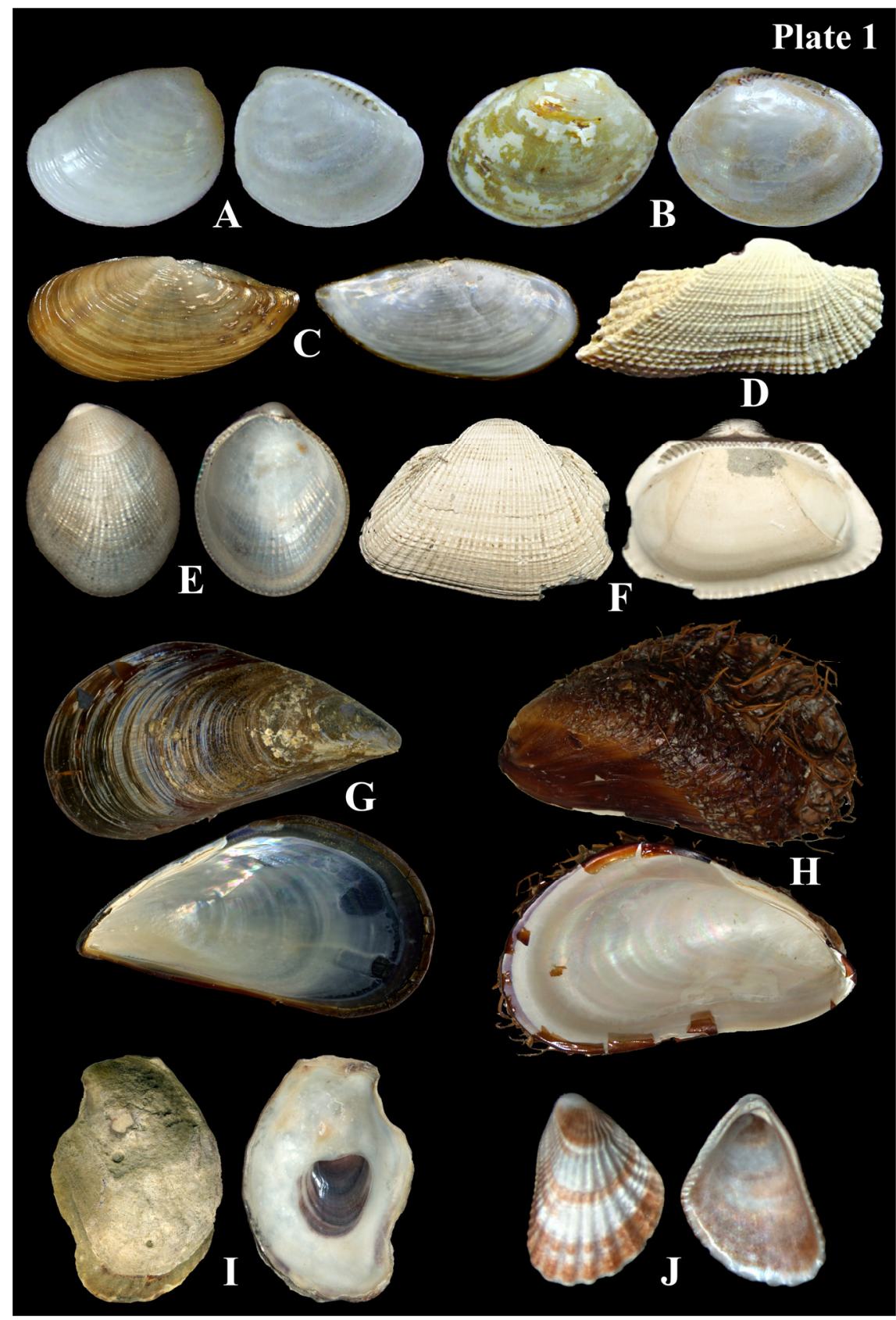

Plate 1. A - Nucula (Nucula) paulula A. Adams, 1856: Ulsan Bay, sta. 3, depth $15 \mathrm{~m}$, shell length $3 \mathrm{~mm}$, ZMFU no. 37732/Bv-5500; B - Nucula (Leionucula) tenuis (Montagu, 1808): Ulsan Bay, sta. 5, depth $43 \mathrm{~m}$, shell length $3 \mathrm{~mm}$, ZMFU no. 37721/Bv-5489; C - Yoldia (Cnesterium) notabilis Yokoyama, 1922: Ulsan Bay, sta. 6, depth $55 \mathrm{~m}$, shell length 32.0 mm, ZMFU no. 26572/Bv-4487; D - Arca boucardi Jousseaume, 1894: Ulsan Bay, sta. 5, depth 43 m, shell length $4.0 \mathrm{~mm}$, ZMFU no. 37691/Bv-5462; E - Crenella decussata (Montagu, 1808): Ulsan Bay, sta. 5, depth 43 m, shell length 3.5 mm, ZMFU no. 37966/Bv-5643; F - Striarca symmetrica (Reeve, 1844): Ulsan Bay, sta. 10, depth 22 m, shell length $11.7 \mathrm{~mm}$, ZMFU no. 26560/Bv-4475; G - Mytilus (Mytilus) galloprovincialis Lamarck, 1819: Ulsan Bay, sta. 11, depth 1-3 m, shell length $54.1 \mathrm{~mm}$, ZMFU no. 26566/Bv-4481; H - Modiolus (Modiolus) kurilensis Bernard, 1983: Ulsan Bay, sta. 11, depth 1-3 m, shell length 25.5 mm, ZMFU no. 26567/Bv-4482; I - Crassostrea gigas (Thunberg, 1793): Ulsan Bay, sta. 5, depth 43 m, shell height 30.0 mm, ZMFU no. 26568/Bv-4483; J - Septifer (Mytilisepta) virgatus (Wiegmann, 1837): Ulsan Bay, sta. 3, depth 15 m, shell length 3.4 mm, ZMFU no. 37965/Bv-5642. 


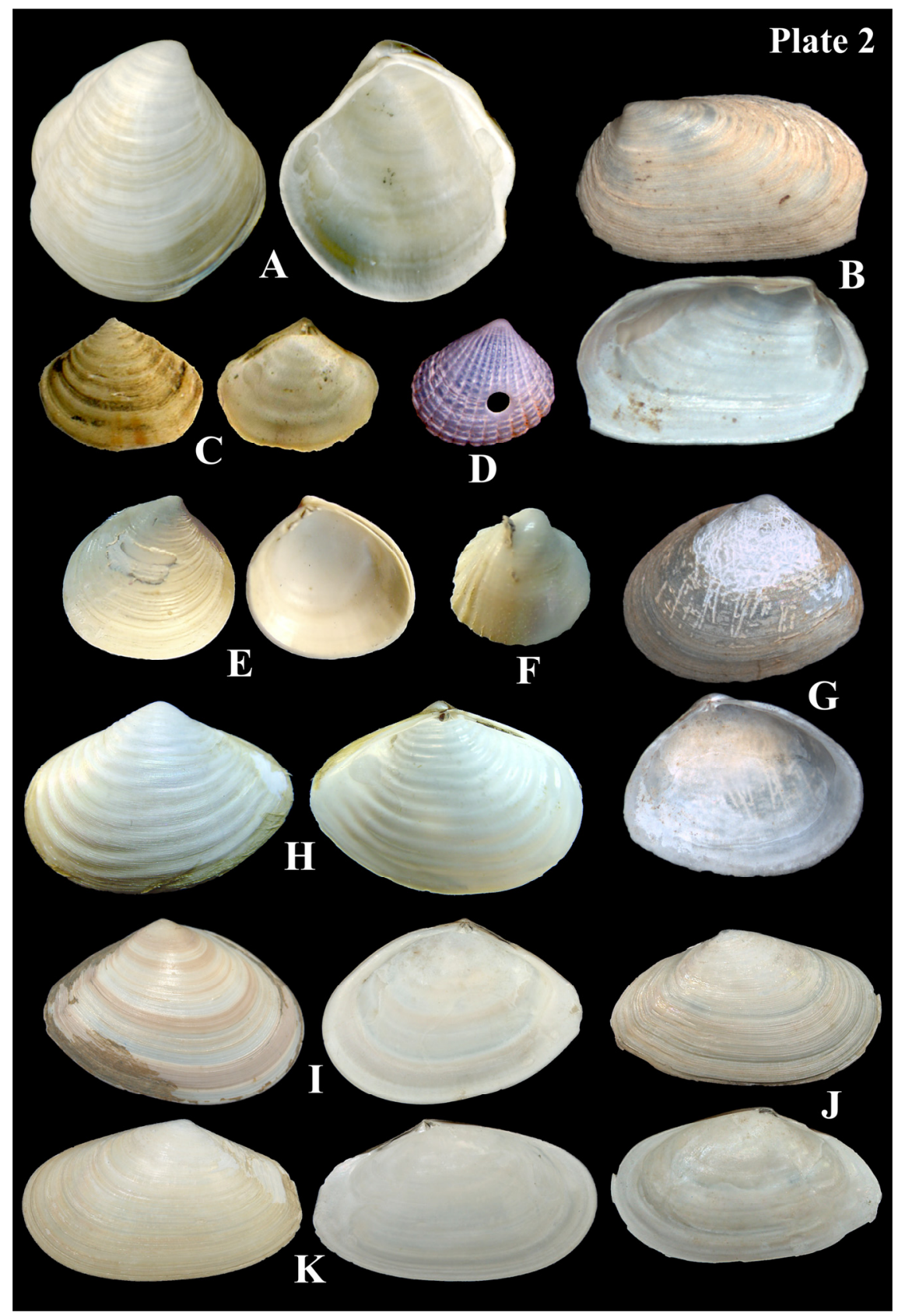

Plate 2. A - Thyasira tokunagai Kuroda et Habe, 1951: Ulsan Bay, sta. 10, depth $22 \mathrm{~m}$, shell length $6.8 \mathrm{~mm}$, ZMFU no. 26575/Bv-4490; B - Nipponomysella oblongata (Yokoyama, 1922): Ulsan Bay, sta. 10, depth $22 \mathrm{~m}$, shell length $5.4 \mathrm{~mm}$, ZMFU no. 37963/Bv-5640; C - Salaputium cf. unicum Hayami et Kase, 1993-: Ulsan Bay, sta. 5, depth 43 m, shell length 3.5 mm, ZMFU no. 26559/Bv-4474-; D - Carditellopsis toneana (Yokoyama, 1922): Ulsan Bay, sta. 3, depth 15 m, shell length $2.0 \mathrm{~mm}$, ZMFU no. 37748/Bv-5516; E - Alveinus ojianus (Yokoyama, 1927): Ulsan Bay, sta. 10, depth 22 m, shell length 3.0 mm, ZMFU no. 37745/Bv-5513; F - Fulvia hungerfordi (G.B. Sowerby III, 1901): Ulsan Bay, sta. 10, depth 22 m, shell length 2.0 mm, ZMFU no. 37690/Bv-5461; G - Macoma (Macoma) incongrua (Martens, 1865): Ulsan Bay, sta. 5, depth $43 \mathrm{~m}$, shell length $8.0 \mathrm{~mm}$, ZMFU no. 37724/Bv-5492; H - Raeta (Raetellops) pulchella (Adams et Reeve, 1850): Ulsan Bay, sta. 5, depth 43 m, shell length 19.7 mm, ZMFU no. 26562/Bv-4477; I - Macoma (Macoma) tokyoensis Makiyama, 1927: Ulsan Bay, sta. 5, depth $43 \mathrm{~m}$, shell length $27.5 \mathrm{~mm}$, ZMFU no. 26565/Bv-4480; J Moerella iridescens (Benson, 1842): Ulsan Bay, sta. 5, depth $43 \mathrm{~m}$, shell length $28.7 \mathrm{~mm}$, ZMFU no. 26574/Bv-4489; K Angulus vestalioides (Yokoyama, 1920): Ulsan Bay, sta. 10, depth $22 \mathrm{~m}$, shell length $24.5 \mathrm{~mm}$, ZMFU no. 26573/Bv-4488. 


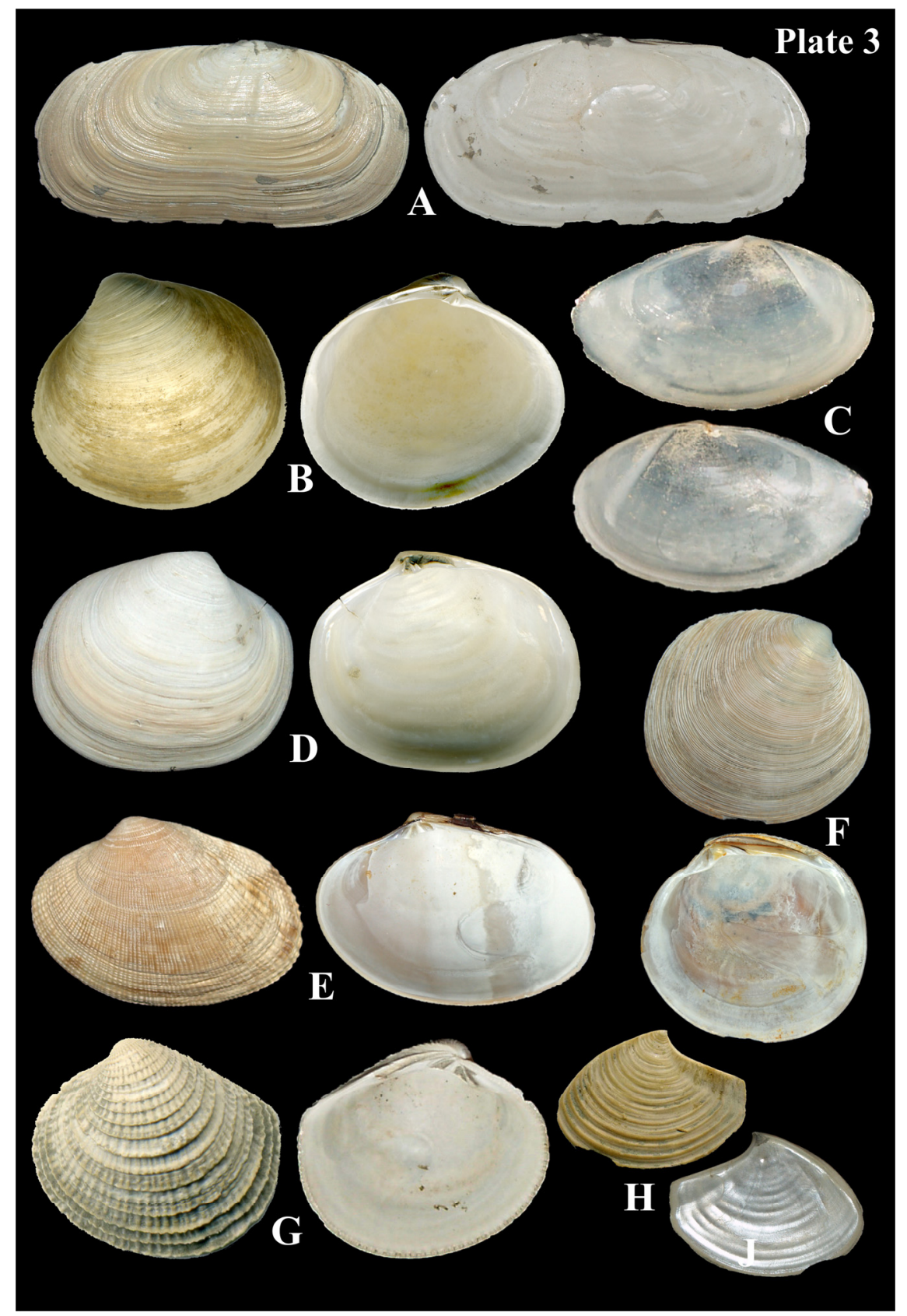

Plate 3. A - Azorinus abbreviatus (Gould, 1861): Ulsan Bay, sta. 10, depth $22 \mathrm{~m}$, shell length $28.9 \mathrm{~mm}$, ZMFU no. 26569/Bv-4484; B - Cycladicama cumingii (Hanley, 1844): Ulsan Bay, sta. 10, depth $22 \mathrm{~m}$, shell length $33.3 \mathrm{~mm}$, ZMFU 26571/Bv-4486; C - Theora (Endopleura) lubrica A.A. Gould, 1861: Ulsan Bay, sta. 2, depth $15 \mathrm{~m}$, shell length $11.2 \mathrm{~mm}$, ZMFU no. 26564/Bv-4479; D - Cycladicama cf. lunaris (Yokoyama, 1927): Ulsan Bay, sta. 9, depth $34 \mathrm{~m}$, shell length 13.7 mm, ZMFU no. 26570/Bv-4485; E - Ruditapes philippinarum (A. Adams et Reeve, 1850): Ulsan Bay, sta. 11, depth 1-3 m, shell length $21.6 \mathrm{~mm}$, ZMFU no. 26558/Bv-4473; F - Dosinia (Dosinella) penicillata (Reeve, 1850): Ulsan Bay, sta. 5, depth $43 \mathrm{~m}$, shell length $46.7 \mathrm{~mm}$, ZMFU no. 26557/Bv-4472; G - Protothaca (Protocallithaca) adamsii (Reeve, 1863): Ulsan Bay, sta. 10, depth 22 m, shell length 8.5 mm, ZMFU no. 26563/Bv-4478; H - Myadora japonica Habe, 1950: Ulsan Bay, sta. 5, depth 43 m, shell length 14.3 mm, ZMFU no. 26561/Bv-4476. 